\title{
Pengaruh Efikasi Diri Dan Beban Kerja Terhadap Kinerja Melalui Kepuasan Kerja Pergawai Pada Kantor Dinas Ketahanan Pangan Dan Peternakan Provinsi Sumatera Utara
}

\author{
Jane Margarentha Sembiring \\ Universitas Muhammadiyah Sumatera Utara Medan, Indonesia \\ janemargaretha@gmail.com
}

\begin{abstract}
The purpose of this study was to examine and analyze the effect of selfefficacy and workload on employee performance through job satisfaction at the Office of Food Security and Animal Husbandry of North Sumatra Province directly or indirectly. The approach used in this study is a causal approach. The population in this study were all state civil servants at the Office of Food Security and Animal Husbandry of North Sumatra Province. The sample in this study used a sample of the slovin formula totaling 69 state civil servants at the Office of Food Security and Animal Husbandry of North Sumatra Province. Data collection techniques in this study used documentation, observation, and questionnaire techniques. The data analysis technique in this study uses a quantitative approach using statistical analysis by using the Auter Model Analysis test, Inner Model Analysis, and Hypothesis Testing. Data processing in this study using the PLS (Partial Least Square) software program. The results of this study prove that directly selfefficacy, workload and job satisfaction have a significant effect on employee performance and indirectly self-efficacy and workload have a significant effect on employee performance through job satisfaction at the Office of Food Security and Animal Husbandry of North Sumatra Province.
\end{abstract}

Keywords Self-Efficacy, Workload, Job Satisfaction and Performance.

\section{PENDAHULUAN}

Dinas Ketahanan Pangan dan Peternakan Provinsi Sumatera Utara adalah Organisasi Perangkat Daerah Pemerintah Provinsi Sumatera Utara berdiri sejak tahun 2017 yang merupakan merger (penggabungan) antara Badan Ketahanan Pangan Provinsi Sumatera Utara dengan Dinas Peternakan dan Kesehatan Hewan Provinsi Sumatera Utara. Dinas Ketahanan Pangan dan Peternakan Provinsi Sumatera Utara adalah unsur pelaksana kontroling dalam hal ketersediaan, distribusi dan keamanan pangan serta ternak dan kesehatan hewan di daerah Sumatera Utara. Dinas Ketahanan Pangan dan Peternakan Provinsi Sumatera Utara merupakan sebuah instansi yang menghasilkan jasa non-profit (tidak berorientasi pada perolehan laba). Dinas Ketahanan Pangan dan Peternakan Provinsi Sumatera Utara memiliki 210 orang ASN (Aparatur Sipil Negara) dimana ASN tersebut bekerja di Sekretariat sebanyak 48 orang, Bidang Konsumsi dan Keamanan Pangan sebanyak 20 orang, Bidang Ketersediaan dan Distribusi Pangan sebanyak 22 orang, Bidang Peternakan sebanyak 20 orang, Bidang Kesehatan Hewan sebanyak 13 orang, UPT Inseminasi Buatan sebanyak 15 orang, UPT Balai Pengawasan Mutu dan Keamanan Pangan sebanyak 17 orang, UPT Kesehatan Masyarakat Veteriner sebanyak 
13 orang, UPT Klinik Hewan sebanyak 10 orang, UPT Pengujian dan Pengembangan Pakan Ternak sebanyak 13 orang, UPT Pembibitan Ternak Ruminansia Lobusona sebanyak 9 orang dan UPT Pembibitan Ternak Sapi dan Unggas Sihitang sebanyak 10 orang. Penulis juga merupakan salah satu ASN Dinas Ketahanan Pangan dan Peternakan di Sekretariat sejak tahun 2010.

Berdasarkan observasi penulis pada kantor Dinas Ketahanan Pangan dan Peternakan Provinsi Sumatera Utara, penulis menemukan beberapa permasalahan pegawai yaitu kinerja pegawai, dimana masih rendahnya kinerja pegawai dalam melakukan pekerjaan. Banyak pegawai yang menyelesaikan pekerjaan dengan kualitas pekerjaan yang rendah serta kuantitas pekerjaan yang kurang memenuhi target pekerjaan yang sudah ditetapkan. Banyak pegawai yang kurang bertanggung jawab dalam menyelesaikan pekerjaannya. Banyak pegawai yang kurang bisa bekerjasama dengan pegawai lainnya serta kurang memiliki inisiatif untuk menyelesaikan pekerjaan sesuai waktu yang telah ditentukan pimpinan. Permasalahan efikasi diri pada Dinas Ketahanan Pangan dan Peternakan Provinsi Sumatera Utara adalah banyak pegawai yang kurang mampu dalam menyelesaikan masalah yang sulit serta kurang mampu menyelesaikan pekerjaan tambahan sehingga menjadi penyebab menurunnya kinerja pegawai. Banyak pegawai yang tidak percaya diri dapat menyelesaikan pekerjaan secara efisien tanpa adanya kejadian yang tidak terduga (masalah).

Permasalahan beban kerja pada Dinas Ketahanan Pangan dan Peternakan Provinsi Sumatera Utara adalah adanya penambahan pekerjaan yang di terima oleh pegawai diluar dari standard pekerjaan yang dimiliki oleh pegawai seperti yang terjadi pada saat ini dengan maraknya wabah virus covid-19 dimana banyaknya perubahan-perubahan masalah pekerjaan sehingga banyak pekerjaan yang ditambah yang di limpahkan kepada beberapa pegawai. Banyak pegawai yang kurang mampu menyelesaikan target pekerjaan setiap hari sehingga menjadi penyebab menurunnya kinerja pegawai. Permasalahan kepuasan kerja pada Dinas Ketahanan Pangan dan Peternakan Provinsi Sumatera Utara adalah ada beberapa pegawai kurang puas dengan hasil pekerjaanya karena hasil pekerjaan yang dilakukan oleh pegawai seringkali tidak dinilai baik oleh pimpinan dan beberapa bidang lainya. Banyak pegawai yang kurang memiliki keahlian yang sesuai dengan tugas pokok dan fungsi dari bidang tersebut. Banyak pegawai yang merasa kurang nyaman dengan lingkungan pekerjaan sehingga pegawai kurang semangat dalam menyelesaikan pekerjaan. Banyak pegawai yang merasa kurang puas dengan pengembangan karir yang ada sehingga menjadi menyebab menurunnya kinerja pegawai tersebut.

\section{LANDASAN TEORI Kinerja}

Kinerja merupakan suatu hasil kerja yang dihasilkan oleh seorang karyawan diartikan untuk mencapai tujuan yang diharapkan. Selain itu kinerja seorang karyawan merupakan hal yang bersifat individual, karena setiap karyawan mempunyai tingkat kemampuan yang berbeda-beda dalam mengerjakan tugasnya. Pihak manajemen dapat mengukur karyawan atas hasil kerjanya berdasarkan kinerja dari masing - masing karyawan. Kinerja dan bukan merupakan hasil yang dapat dilihat pada saat itu juga. Pada dasarnya kinerja merupakan sesuatu hal yang bersifat individual, karena setiap karyawan memiliki tingkat kemampuan yang berbeda dalam mengerjakan tugasnya. Menurut (Mangkunegara, 2014) berpendapat bahwa kinerja karyawan adalah hasil kerja secara 
kualitas dan kuantitas yang dicapai oleh seseorang karyawan dalam melaksanakan tugasnya sesuai dengan tanggung jawab yang diberikan kepadanya.

Menurut (Wibowo, 2010) menyatakan bahwa kinerja berasal darikata performance yang berarti hasil pekerjaan atau prestasi kerja. Namun perlu dipahami bahwa kinerja itu bukan sekedar hasil pekerjaan atau prestasi kerja, tetapi juga mencakup bagaimana proses pekerjaan itu berlangsung. Menurut (Nooralizad et al., 2011) "Kinerja sebagai sesuatu yang tampak, dimana individu relavan dengan tujuan organisasi. Kinerja yang baik merupakan salah satu sasaran organisasi dalam pencapaian produktivitas kerja yang tinggi. Tercapainya kinerja yang baik tidak terlepas dari kualitas sumber daya manusia yang baik pula. Dari pengertian para ahli diatas dapat disimpulkan peneliti kinerja sebagai kualitas dan kuantitas pencapaian tugas-tugas, baik yang dilakukan oleh individu, kelompok maupun perusahaan.

\subsubsection{Indikator Kinerja}

Indikator kinerja merupakan sesuatu yang akan dihitung dan diukur. Adapun indikator kinerja (Mangkunegara, 2014) menyatakan yaitu :

1. Kualitas kerja. Kualitas kerja adalah mutu yang harus dihasilkan dalam pekerjaan.

2. Kuantitas kerja. Kuantitas kerja adalah jumlah yang harus diselesaikan dan dicapai dalam pekerjaan.

3. Dapat tidaknya diandalkan. Dapat tidaknya diandalkan merupakan apakah seseorang karyawan dapat mengikuti instruksi, memiliki inisiatif, hati-hati dan rajin dalam bekerja.

4. Sikap. Sikap yang dimiliki terhadap perusahaan, karyawan lain pekerjaan secara kerjasama. Sedangkan menurut (Sutrisno, 2010) mengemukakan bahwa dimensi dan indikator kinerja dapat diukur yaitu sebagai berikut:

5. Kualitas Kerja. Kualitas kerja adalah seberapa baik seseorang karyawan mengerjakan apa yang seharusnya dikerjakan.

6. Kuantitas Kerja. Kuantitas kerja adalah seberapa lama seseorang karyawan bekerja dalam satu harinya. Kuantitas kerja ini dapat dilihat dari kecepatan kerja setiap karyawan itu masing-masing.

7. Tanggung Jawab. Tanggung jawab terhadap pekerjaan adalah kesadaran akan kewajiban karyawan untuk melaksanankan pekerjaan yang diberikan perusahaan.

8. Kerjasama. Kesediaan karyawan untuk berpartisipasi dengan karyawan atau pegawai lain secara vertikal dan horizontal baik didalam maupun diluar pekerjaan sehingga hasil pekerjaan semakin baik.

9. Inisiatif. Inisiatif dari dalam diri anggota perusahaan untuk melakukan pekerjaan serta mengatasi masalah dalam pekerjaan tanpa menunggu perintah dari atasan atau menunjukan tanggung jawab dalam pekerjaan yang sudah menjadi kewajiban karyawan maupun pegawai.

\section{Efikasi Diri}

Efikasi diri adalah keyakinan individu akan kemampuan yang dimiliki dalam hal melakukan tugas atau tindakan yang diperlukan untuk mencapai tujuan. Seorang dengan efikasi diri yang tinggi mereka percaya mampu melakukan sesuatu untuk mengubah kejadian-kejadian disekitarnya, sedangkan seseorang yang memiliki efikasi diri rendah menganggap dirinya tidak mampu mengerjakan segala sesuatu yang ada disekitarnya. Dalam situasi yang sulit orang dengan self efficacy yang rendah akan mudah menyerah sementara self efficacy yang tinggi akan berusaha lebih keras untuk mengatasi tantangan 
yang ada. Menurut (Ghufron \& Risnawati, 2010) mendefinisikan self-efficacy (efikasi diri) sebagai evaluasi seseorang mengenai kemampuan atau kompetensi dirinya untuk melakukan suatu tugas, mencapai tujuan, dan mengatasi hambatan. Meskipun Bandura menganggap self efficacy terjadi pada suatu fenomena situasi khusus, para peneliti lain telah membedakan selfefficacy secara umum atau generalized self efficacy. Pada self efficacy secara umum menggambarkan suatu penilaian diri seberapa baik seseorang dapat melakukan suatu perbuatan pada situasi yang beraneka ragam. Sedangkan menurut (Feist \& Feist, 2010) self efficacy adalah keyakinan seseorang dalam kemampuannya untuk melakukan suatu bentuk kontrol terhadap fungsi orang itu sendiri dan kejadian dalam lingkungan.

\section{Indikator Efikasi Diri}

Seorang dengan efikasi diri yang tinggi mereka percaya mampu melakukan sesuatu untuk mengubah kejadian-kejadian disekitarnya, sedangkan seseorang yang memiliki efikasi dirirendah menganggap dirinya tidak mampu mengerjakan segala sesuatu yang ada disekitarnya. Menurut (Bandura, 2010) ada empat indikator dalam menghukur self efficacy antara lain:

\section{Past performance}

Merupakan sumber informasi self efficacy yang paling berpengaruh. Dari pengalaman masa lalu terlihat bukti apakah seseorang mengarahkan seluruh kemampuannya untuk meraih keberhasilan.

\section{Vicarious experience}

Merupakan cara meningkatkan self efficacy dari pengalaman keberhasilan yang telah ditunjukkan oleh orang lain. Ketika melihat orang lain dengan kemampuan yang sama berhasil dalam suatu bidang atau tugas melalui usaha yang tekun, individu juga akan merasa yakin bahwa dirinya juga dapat berhasil dalam bidang tersebut dengan usaha yang sama. Sebaliknya self efficacy dapat turun ketika orang yang diamati gagal walaupun telah berusaha dengan keras. Individu juga akan ragu untuk berhasil dalam bidang tersebut.

\section{Verbal persuasion}

Digunakan secara luas untuk membujuk seseorang bahwa mereka mempunyai kemampuan untuk mencapai tujuan yang diharapkan. Orang yang mendapat persuasi secara verbal maka mereka memiliki kemampuan untuk menyelesaikan tugas-tugas yang diberikan, akan mengerahkan usaha yang lebih besar daripada orang yang tidak dipersuasi bahwa dirinya mampu pada bidang tersebut.

\section{Emotional cues}

Ketika seseorang percaya bahwa sebagian tanda-tanda psikologis menghasilkan informasi dalam menilai kemampuannya. Kondisi stress dan kecemasan dilihat individu sebagai tanda yang mengancam ketidakmampuan diri. Ketika seseorang menghadapi suatu tugas, apakah cemas atau khawatir (self efficacy rendah) atau tertarik (self efficacy tinggi) dapat memberikan informasi mengenai self efficacy orang tersebut. Dalam menilai kemampuannya seseorang dipengaruhi oleh informasi tentang keadaan fisiknya untuk menghadapi situsasi tertentu dengan memperhatikan keadaan fisiologisnya.

\section{Beban Kerja}

Beban kerja adalah suatu jumlah pekerjaan yang diberikan kepada seseorang untuk diselesaikan dalam kurun waktu tertentu. Menurut (Tarwaka, 2014) menyimpulkan: "beban kerja merupakan suatu yang muncul dari interaksi antara tuntutan 
tugas, lingkungan kerja dimana digunakan sebagai tempat kerja, ketrampilan perilaku dan persepsi dari pekerjaan." Sedangkan menurut Permendagri Nomor 12 tahun 2008, beban kerja adalah besaran pekerjaan yang harus dipikul oleh suatu jabatan/unit organisasi dan merupakan hasil kali antara volume kerja dan norma waktu. Selanjutnya berdasarkan Undang - undang Kesehatan Nomor 36 tahun 2009 bahwa beban kerja adalah besaran pekerjaan yang harus dipikul oleh suatu jabatan/unit organisasi dan merupakan hasil antara jumlah pekerjaan dengan waktu. Setiap pekerja dapat bekerja secara sehat tanpa membahayakan dirinya sendiri maupun masyarakat di sekelilingnya, untuk itu perlu dilakukan upaya penyerasian antara kapasitas kerja, beban kerja dan lingkungan kerja sehingga diperoleh hasil kerja yang optimal.

Sedangkan Menurut (Moekijat, 2010) beban kerja adalah volume dari hasil kerja atau catatan tentang hasil pekerjaan yang dapat menunjukan volume yang dihasilkan oleh sejumlah pegawai dalam suatu bagian tertentu. Jumlah pekerjaan yang harus diselesaikan oleh sekelompok atau seseorang dalam waktu tertentu atau beban kerja dapat dilihat pada sudut pandang obyektif dan subyektif. Secara obyektif adalah keseluruhan waktu yang dipakai atau jumlah aktivitas yang dilakukan. Sedangkan beban kerja secara subyektif adalah ukuran yang dipakai seseorang terhadap pernyataan tentang perasaan kelebihan beban kerja, ukuran dari tekanan pekerjaan dan kepuasan kerja. Beban kerja sebagai sumber ketidakpuasan disebabkan oleh kelebihan beban kerja.

\section{Indikator Beban kerja}

Menurut (Tarwaka, 2014) Beban kerja adalah "sekumpulan atau sejumlah kegiatan yang harus diselesaikan oleh suatu unit organisasi atau pemegang jabatan dalam jangka waktu tertentu." Beban kerja memuat 3 indikator, yaitu:

1. Beban waktu (time load), menunjukkan jumlah waktu yang tersedia dalam perencanaan, pelaksanaan dan monitoring tugas.

2. Beban usaha mental (mental effort load), yang berarti banyaknya usaha mental dalam melaksanakan suatu pekerjaan.

3. Beban tekanan psikologis (psychologis stress load) yang menunjukkan tingkat risiko pekerjaan, kebingungan dan frustasi.

\section{Kepuasan Kerja}

Kepuasan kerja merupakan salah satu elemen yang cukup penting dalam salah satu organisasi. Hal ini disebabkan kepuasan kerja dapat mempengaruhi perilaku kerja seperti malas, rajin, produktif, dan lain-lain, atau mempunyai hubungan dengan beberapa jenis perilaku yang sangat penting dalam organisasi. Menurut (E Sutrisno, 2010) "kepuasan kerja karyawan merupakan masalah penting yang diperhatikan dalam hubungannya dengan produktivitas kerja karyawan dan ketidakpuasan sering dikaitkan dengan tingkat tuntutan dan keluhan pekerjaan yang tinggi. Pekerja dengan tingkat ketidakpuasan yang tinggi lebih mungkin untuk melakukan sabotase dan agresi yang pasif".

Menurut (Yulianita, 2017) "kepuasan kerja merupakan salah satu elemen yang cukup penting dalam salah satu organisasi. Hal ini disebabkan kepuasan kerja dapat mempengaruhi perilaku kerja seperti malas, rajin, produktif, dan lain-lain, atau mempunyai hubungan dengan beberapa jenis perilaku yang sangat penting dalam organisasi". Munurut (Handoko, 2013) "kepuasan kerja adalah keadaan emosional yang menyenangkan atau tidak menyenangkan dengan mana para karyawan memandang pekerjaan mereka".Sedangkan Menurut (Siagian, 2014) kepuasan kerja merupakan suatu 
cara pandang seseorang baik yang bersifat positif maupun yang bersifat negatif tentang pekerjaannya.

\section{Indikator Kepuasan Kerja}

Tolak ukur kepuasan kerja yang mutlak sulit untuk dicari karena setiap individu karyawan berbeda standar kepuasannya. Adapun indikator-indikator kepuasan kerja menurut (Hasibuan, 2010) antara lain:

1. Kesetiaan. Penilai mengukur kesetiaan karyawan terhadap pekerjaannya, jabatannya, dan organisasi. Kesetiaan ini dicerminkan oleh kesediaan karyawan menjaga dan membela organisasi didalam maupun diluar pekerjaannya dari rongrongan orang yang tidak bertanggung jawab.

2. Kemampuan. Penilai menilai hasil kerja baik kualitas maupun kuantitas yang dapat dihasilkan karyawan tersebut dari uraian pekerjaannya.

3. Kejujuran. Penilai menilai kejujuran dalam melaksanakan tugas-tugasnya memenuhi perjanjian baik bagi dirinya sendiri maupun terhadap orang lain.

4. Kreatifitas. Penilai menilai kemampuan karyawan dalam mengembangkan kreativitasnya untuk menyelesaikan pekerjaannya, sehingga akan dapat bekerja lebih baik.

5. Kepemimpinan. Penilai menilai kemampuan untuk memimpin, mempunyai pribadi yang kuat, dihormati, berwibawa dan dapat memotivasi orang lain atau bawahannya untuk bekerja secara efektif.

6. Tingkat Gaji. Penilai menilai jumlah gaji yang diberikan perusahaan dan diterima karyawan harus sesuai dengan apa yang karyawan berikan terhadap perusahaan agar mereka merasa puas.

7. Kompensasi Tidak Langsung. Penilai menilai pemberian balas jasa yang memadai dan layak kepada para karyawan atas kontribusi mereka membantu perusahaan mencapai tujuannya. Pemberian balas jasa atau imbalan atas tenaga, waktu, fikiran serta prestasi yang telah diberikan karyawan kepada perusahaan.

8. Lingkungan Kerja Penilai menilai lingkungan kerja yang baik dapat membuat karyawan merasa nyaman dalam bekerja.

\section{Pengembangan Hipotesis}

\section{Hubungan Efikasi Diri Terhadap Kinerja}

Efikasi diriadalah keyakinan individu akan kemampuan yang dimiliki dalam hal melakukan tugas atau tindakan yang diperlukan untuk mencapai tujuan. Seorang dengan efikasi diriyang tinggi mereka percaya mampu melakukan sesuatu untuk mengubah kejadian-kejadian disekitarnya, sedangkan seseorang yang memiliki efikasi dirirendah menganggap dirinya tidak mampu mengerjakan segala sesuatu yang ada disekitarnya. Dalam situasi yang sulit orang dengan self efficacy yang rendah akan mudah menyerah sementara self efficacy yang tinggi akan berusaha lebih keras untuk mengatasi tantangan yang ada. Self-efficacy merupakan salah satu kemampuan pengaturan diri individu (Muis et al., 2018).

H1 : Efikasi diri berpengaruh terhadap kinerja.

\section{Hubungan Beban Kerja Terhadap Kinerja}

Beban kerja adalah sekumpulan atau sejumlah kegiatan yang harus diselesaikan oleh suatu unit organisasi atau pemegang jabatan dalam jangka waktu tertentu (Taurisa \& Ratnawati, 2012). Beban kerja sesungguhnya dapat memberikan manfaat untuk sarana 
peningkatan kinerja baik secara perorangan maupun secara kelembagaan atau organisasi. Beban kerja yang disesuaikan dengan keterampilan dan kebutuhan dari posisi tentu akan lebih bisa mengarahkan karyawan dalam bekerja secara efektif dan efisien. Hubungan beban kerja terhadap kinerja adalah kompleks, bisa mengakibatkan kinerja yang tinggi maupun kinerja yang rendah (Nachreiner, dalam (Chaterina, 2012). Beban kerja yang tidak sesuai dengan kemampuan karyawan dapat mengakibatkan karyawan tidak bekerja dengan lebih baik atau optimal.

Beban kerja yang terlalu rendah juga dapat menurunkan tingkat kinerja karyawan. Apabila terlalu rendah beban kerja yang diamanatkan kemampuan yang ada dalam diri karyawan tidak dapat dipergunakan dengan maksimal. Selain itu juga dapat menimbulkan kebosanan kehilangan perhatian maupun kosentrasi, mengurangi kepekaan terhadap lingkungan sekitar (Saraswati et al., 2017)

$\mathrm{H} 2$ : Beban kerja berpengaruh terhadap kinerja.

\section{Hubungan Kepuasan Kerja Terhadap Kinerja}

Kepuasan kerja merupakan hal yang bersifat individual dan tergantung pada persepsi seseorang tentang apa yang dirasakannya mengenai pekerjaan. Menurut (Hasibuan, 2010). Kepuasan yang tinggi sebagaimana diungkapkan dalam pengertian diatas, akan memberikan suatu pilihan untuk menyokong (favorableness) atau tidak menyokong (unfavorableness) pada pekerjannya. Tentu saja pilihan tersebut akan mempengarui bagaimana karyawan atau individu tersebut melaksanakan pekerjaannya. Implikasi adanya ketidakpuasan adalah meningkatkan turnover, ketidakhadiran, maupun tingkat pekerjaan. Ini artinya bahwa kepuasan kerja akan mengurangi ketidakkerasanan karyawan dalam bekerja, meningkatkan jumlah kehadiran maupun kinerjanya (Mangkunegara, 2014).

H3: Kepuasan kerja berpengaruh terhadap kinerja.

\section{Hubungan Efikasi Diri terhadap Kepuasan Kerja}

Efikasi diri tinggi cenderung tidak mudah putus asa jika menghadapi kesulitankesulitan pekerjaan. Bagaimanapun rumitnya tugas dan pekerjaan yang harus dilakukan, orang dengan self efficacy tinggi akan cenderung termotivasi untuk dapat menyelesaikan, tidak ada motivasi untuk meninggalkan pekerjaan atau organisasinya hanya karena adanya kesulitan atau rintangan dalam menjalankan tugas dan pekerjaan (Subagyo, 2014). Semakin baik penerapan efikasi diri, maka kepuasan kerja pegawai semakin meningkat dimana ketika individu mengalami kesenangan dalam bekerja, maka mereka akan melakukan pekerjaan lain di luar persepsi peran mereka atau kewajiban.

H4 : Efikasi diri mempunyai pengaruh positif terhadap kepuasan kerja.

\section{Hubungan Beban Kerja Kerja terhadap Kepuasan Kerja}

Apabila seseorang memikul beban pekerjaan yang terlalu berat dan merasa tertekan maka besar kemungkinan orang tersebut akan merasakan ketidakpuasan terhadap pekerjaannya. Beban kerja yang terlalu berat yang disebabkan semakin ketatnya persaingan akan membuat karyawan lebih cepat mengalami stress dan kepanikan, sehingga tidak dapat menikmati pekerjaannya lagi. Karenanya porsi dari pembagian dari beban kerja harus disesuaikan dengan kemampuan atau kapasitas seseorang dalam menyelesaikan pekerjaannya (Bawono \& Nugraheni, 2015). Menurut (Tarwaka, 2014) menyimpulkan: "beban kerja merupakan suatu yang muncul dari interaksi antara tuntutan 
tugas, lingkungan kerja dimana digunakan sebagai tempat kerja, keterampilan perilaku dan persepsi dari pekerjaan.

H5 : Beban kerja berpengaruh signifikan terhadap kepuasan kerja.

\section{METODOLOGI PENELITIAN}

Penelitian dilaksanakan mulai bulan Januari 2021 sampai dengan Juli 2021, penelitian ini adalah penelitian survey, penelitian kausal, penelitian kuantitatif. Penelitian ini dilaksanakan di kantor Dinas Ketahanan Pangan Dan Peternakan Provinsi Sumatera Utara Jl. Jend. Gatot Subroto No. 255 , Km.7, Lalang, Medan, Kota Medan, Sumatera Utara 20127. Populasi dalam penelitian ini adalah seluruh pegawai yang terdapat pada kantor Dinas Ketahanan Pangan Dan Peternakan Provinsi Sumatera Utara berjumlah 210 orang. jumlah sampel dalam penelitian ini adalah sebanyak 68 orang pegawai Dinas Ketahanan Pangan Dan Peternakan Provinsi Sumatera Utara. Pengambilan sampel ini menggunakan metode Nonprobability Sampling dengan menggunakan teknik Insidental sampling

\section{HASIL DAN PEMBAHASAN}

\section{Pengujian Hipotesis}

Pengujian ini adalah untuk menentukan koefisien jalur dari model struktural. Tujuannya adalah menguji signifikansi semua hubungan atau pengujian hipotesis. Pengujian hipotesis dalam penelitian ini dibagi menjadi pengaruh langsung dan pengaruh tidak langsung. Berdasarkan pengolahan data yang telah dilakukan dengan menggunakan program smartPLS 3.0, gambar hasil uji hipotesis pengaruh langsung dan tidak langsung dapat dilihat pada gambar path coefficient berikut ini :

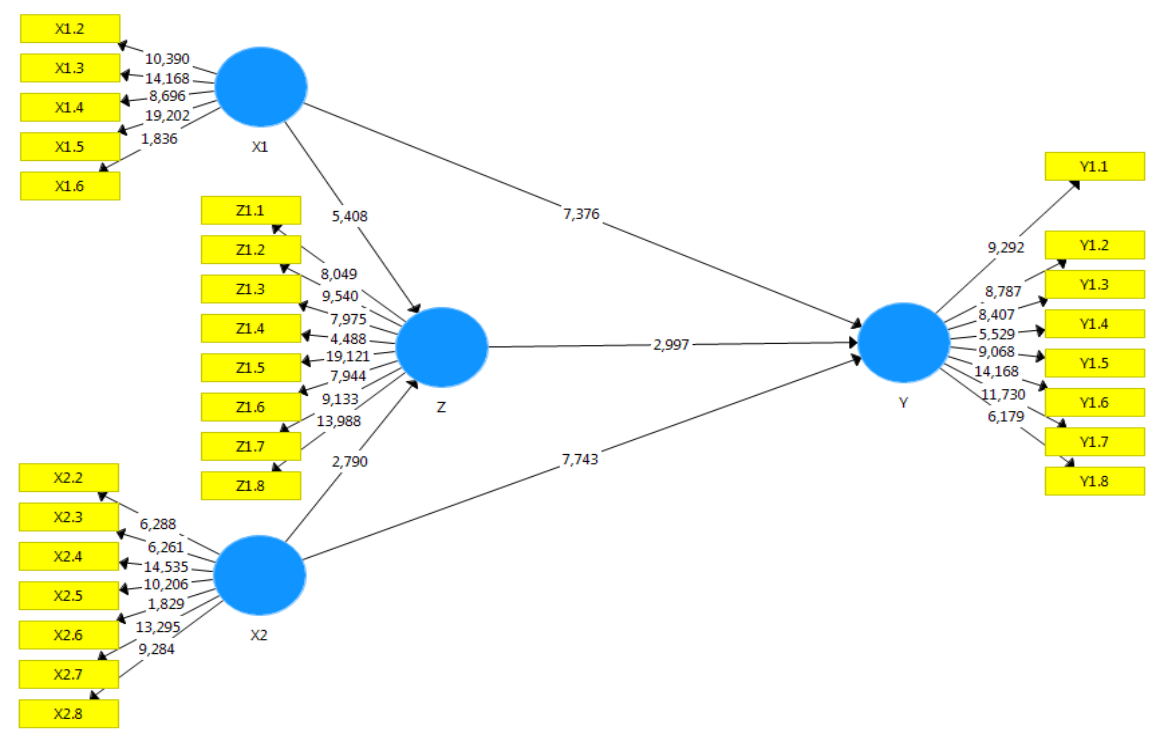

Gambar 1. Path Coefficient

Hasil uji hipotesis pengaruh langsung dapat dilihat pada tabel path coefficient berikut ini:

Tabel 1. Path Coefficient

\begin{tabular}{|l|l|l|l|l|l|}
\hline & $\begin{array}{l}\text { Original } \\
\text { Sample (O) }\end{array}$ & $\begin{array}{l}\text { Sample } \\
\text { Mean }(\mathbf{M})\end{array}$ & $\begin{array}{l}\text { Standard Error } \\
(\text { STERR })\end{array}$ & $\begin{array}{l}\text { T Statistics } \\
(\mid \text { O/STERR })\end{array}$ & P Values \\
\hline
\end{tabular}




\begin{tabular}{|l|l|l|l|r|r|}
\hline $\mathbf{X 1}$-> Y & 0,439 & 0,444 & 0,060 & 7,376 & $\mathbf{0 . 0 0 0}$ \\
\hline $\mathbf{X 1}$-> Z & 0,565 & 0,556 & 0,105 & 5,408 & $\mathbf{0 . 0 0 0}$ \\
\hline $\mathbf{X 2}$-> Y & 0,450 & 0,446 & 0,058 & 7,743 & $\mathbf{0 . 0 0 0}$ \\
\hline $\mathbf{X 2}$-> Z & 0,320 & 0,328 & 0,115 & 2,790 & $\mathbf{0 . 0 0 5}$ \\
\hline $\mathbf{Z}$-> Y & 0,170 & 0,174 & 0,057 & 2,997 & $\mathbf{0 . 0 0 3}$ \\
\hline
\end{tabular}

Sumber : PLS 3.00

Berdasarkan Tabel 1 di atas, dapat dinyatakan bahwa pengujian hipotesis adalah sebagai berikut:

1. Pengaruh efikasi diri terhadap kinerja mempunyai koefisien jalur sebesar 0,439 . Pengaruh tersebut mempunyai nilai probabilitas (p-values) sebesar $0,000<0,05$, berarti efikasi diri berpengaruh signifikan terhadap kinerja pegawai pada kantor Dinas Ketahanan Pangan Dan Peternakan Provinsi Sumatera Utara.

2. Pengaruh efikasi diri terhadap kepuasan kerja mempunyai koefisien jalur sebesar 0,565 . Pengaruh tersebut mempunyai nilai probabilitas (p-values) sebesar $0,000<$ 0,05 , berarti efikasi diri berpengaruh signifikan terhadap kepuasan kerja pegawai pada kantor Dinas Ketahanan Pangan Dan Peternakan Provinsi Sumatera Utara..

3. Pengaruh beban kerja terhadap kinerja mempunyai koefisien jalur sebesar $-0,450$. Pengaruh tersebut mempunyai nilai probabilitas (p-values) sebesar 0,000 $<0,05$, berarti baban kerja berpengaruh signifikan terhadap kinerja pegawai pada kantor kantor Dinas Ketahanan Pangan Dan Peternakan Provinsi Sumatera Utara.

4. Pengaruh beban kerja terhadap kepuasan kerja mempunyai koefisien jalur sebesar 0,320 . Pengaruh tersebut mempunyai nilai probabilitas ( $\mathrm{p}$-values) sebesar $0,005<$ 0,05 , berarti beban kerja berpengaruh signifikan terhadap kepuasan kerja pegawai pada kantor kantor Dinas Ketahanan Pangan Dan Peternakan Provinsi Sumatera Utara..

5. Pengaruh kepuasan kerja terhadap kinerja mempunyai koefisien jalur sebesar -170 . Pengaruh tersebut mempunyai nilai probabilitas (p-values) sebesar 0,003 $<0,05$, berarti kepuasan kerja berpengaruh signifikan terhadap kinerja pegawai pada kantor kantor Dinas Ketahanan Pangan Dan Peternakan Provinsi Sumatera Utara.

Tabel 2. Specific Indirect Effects

\begin{tabular}{|l|r|l|l|r|r|}
\hline & $\begin{array}{l}\text { Original } \\
\text { Sample (O) }\end{array}$ & $\begin{array}{l}\text { Sample } \\
\text { Mean } \\
(\mathbf{M})\end{array}$ & $\begin{array}{l}\text { Standard } \\
\text { Deviation } \\
\text { (STDEV) }\end{array}$ & $\begin{array}{l}\text { T Statistics } \\
\text { (|O/STDEV|) }\end{array}$ & P Values \\
\hline X1 -> Z -> Y & 0.096 & 0.096 & 0.034 & 2,828 & $\mathbf{0 . 0 0 5}$ \\
\hline X2 -> Z -> Y & 0.054 & 0.058 & 0.031 & 2,732 & $\mathbf{0 . 0 0 8}$ \\
\hline
\end{tabular}

Sumber : PLS 3.00

Berdasarkan Tabel 2 di atas, dapat dinyatakan bahwa pengujian hipotesis adalah sebagai berikut:

1. Pengaruh efikasi diri terhadap kinerja melalui kepuasan kerja mempunyai koefisien jalur sebesar 0,054. Pengaruh tersebut mempunyai nilai probabilitas ( $\mathrm{p}$-values) sebesar $0,005<0,05$, berarti dapat disimpulkan bahwa efikasi diri berpengaruh signifikan terhadap kinerja pegawai melalui kepuasan kerja pegawai pada kantor kantor Dinas Ketahanan Pangan Dan Peternakan Provinsi Sumatera Utara..

2. Pengaruh beban kerja terhadap kinerja melalui kepuasan kerja mempunyai koefisien jalur sebesar 0,054. Pengaruh tersebut mempunyai nilai probabilitas ( $p$-values) sebesar $0,008<0,05$, berarti dapat disimpulkan bahwa beban kerja berpengaruh signifikan terhadap kinerja pegawai melalui kepuasan kerja pegawai pada kantor kantor Dinas Ketahanan Pangan Dan Peternakan Provinsi Sumatera Utara. 


\section{PEMBAHASAN}

\section{Pengaruh Efikasi Diri Terhadap Kinerja}

Dari hasil analisis pengujian hipotesis diketahui bahwa efikasi diri berpengaruh signifikan terhadap kinerja yang dinilai dengan koefisien jalur sebesar 0,439. Nilai probabilitas yang didapatkan adalah sebesar $0,000<0,05$, dengan nilai $t_{\text {hitung }}$ sebesar 7,376 , dan nilai $t_{\text {tabel }} 1.96$, dengan demikian $t_{\text {hitung }}$ lebih besar dari $t_{\text {tabel }}(7,376>1.96)$ sehingga $\mathrm{H0}$ ditolak (Ha diterima). Hal ini berarti efikasi diri berpengaruh signifikan terhadap kinerja pegawai pada kantor Dinas Ketahanan Pangan Dan Peternakan Provinsi Sumatera Utara. Efikasi diri adalah keyakinan individu akan kemampuan yang dimiliki dalam hal melakukan tugas atau tindakan yang diperlukan untuk mencapai tujuan. Seorang dengan efikasi diri yang tinggi mereka percaya mampu melakukan sesuatu untuk mengubah kejadian-kejadian disekitarnya, sedangkan seseorang yang memiliki efikasi diri rendah menganggap dirinya tidak mampu mengerjakan segala sesuatu yang ada disekitarnya. Dalam situasi yang sulit orang dengan self efficacy yang rendah akan mudah menyerah sementara self efficacy yang tinggi akan berusaha lebih keras untuk mengatasi tantangan yang ada. Self-efficacy merupakan salah satu kemampuan pengaturan diri individu (Muis et al., 2018).

Menurut (Feist \& Feist, 2010) self efficacy adalah keyakinan seseorang dalam kemampuannya untuk melakukan suatu bentuk kontrol terhadap fungsi orang itu sendiri dan kejadian dalam lingkungan. Menurut (Subagyo, 2014) self efficacy tinggi cenderung tidak mudah putus asa jika menghadapi kesulitan-kesulitan pekerjaan. Bagaimanapun rumitnya tugas dan pekerjaan yang harus dilakukan, orang dengan self efficacy tinggi akan cenderung termotivasi untuk dapat menyelesaikan, tidak ada motivasi untuk meninggalkan pekerjaan atau organisasinya hanya karena adanya kesulitan atau rintangan dalam menjalankan tugas dan pekerjaan. Hasil penelitian ini sejalan dengan hasil penelitian terdahulu yang dilakukan oleh (Saraswati et al., 2017) menyimpukan bahwa efikasi diri berpengaruh terhadap kinerja.

\section{Pengaruh Beban Kerja Terhadap Kinerja}

Dari hasil analisis pengujian hipotesis diketahui bahwa beban kerja berpengaruh signifikan terhadap kinerja yang dinilai dengan koefisien jalur sebesar 0,450. Nilai probabilitas yang didapatkan adalah sebesar $0,000<0,05$, dengan nilai $t_{\text {hitung }}$ sebesar 7,743 , dan nilai $t_{\text {tabel }} 1.96$, dengan demikian $t_{\text {hitung }}$ lebih besar dari $t_{\text {tabel }}(7,743>1.96)$ sehingga $\mathrm{H} 0$ ditolak (Ha diterima). Hal ini berarti beban kerja berpengaruh signifikan terhadap kinerja pegawai pada kantor Dinas Ketahanan Pangan Dan Peternakan Provinsi Sumatera Utara.

Beban kerja sesungguhnya dapat memberikan manfaat untuk sarana peningkatan kinerja baik secara perorangan maupun secara kelembagaan atau organisasi. Beban kerja yang disesuaikan dengan keterampilan dan kebutuhan dari posisi tentu akan lebih bisa mengarahkan karyawan dalam bekerja secara efektif dan efisien. Hubungan beban kerja terhadap kinerja adalah kompleks, bisa mengakibatkan kinerja yang tinggi maupun kinerja yang rendah (Nachreiner, dalam (Chaterina, 2012). Beban kerja yang tidak sesuai dengan kemampuan karyawan dapat mengakibatkan karyawan tidak bekerja dengan lebih baik atau optimal. Beban kerja yang terlalu rendah juga dapat menurunkan tingkat kinerja karyawan. Apabila terlalu rendah beban kerja yang diamanatkan kemampuan yanga da dalam diri karyawan tidak dapat dipergunakan dengan maksimal. Selain itu juga dapat menimbulkan kebosanan kehilangan perhatian maupun kosentrasi, mengurangi kepekaan terhadap lingkungan sekitar (Saraswati et al., 2017). Beban kerja adalah sekumpulan atau 
sejumlah kegiatan yang harus diselesaikan oleh suatu unit organisasi atau pemegang jabatan dalam jangka waktu tertentu (Taurisa \& Ratnawati, 2012). Hasil penelitian ini sejalan dengan hasil penelitian terdahulu yang dilakukan oleh (Dwi, 2020) dan (Rolos et al., 2018) menyimpulkan bahwa beban kerja berpengaruh terhadap kinerja.

\section{Pengaruh Kepuasan Kerja Terhadap Kinerja}

Dari hasil analisis pengujian hipotesis diketahui bahwa kepuasan kerja berpengaruh signifikan terhadap kinerja yang dinilai dengan koefisien jalur sebesar 0,170 . Nilai probabilitas yang didapatkan adalah sebesar $0,003<0,05$, dengan nilai thitung sebesar 2,997, dan nilai $t_{\text {tabel }} 1.96$, dengan demikian $t_{\text {hitung }}$ lebih besar dari $t_{\text {tabel }}$ (2,997>1.96) sehingga H0 ditolak (Ha diterima). Hal ini berarti kepuasan kerja berpengaruh signifikan terhadap kinerja pegawai pada Dinas Ketahanan Pangan Dan Peternakan Provinsi Sumatera Utara. Dalam hal ini pimpinan diharapakan agar lebih cermat untuk menempatkan pegawai yang sesuai dengan kehlian dan kompetensi pegawai tersebut.

Kepuasan yang tinggi sebagaimana diungkapkan dalam pengertian diatas, akan memberikan suatu pilihan untuk menyokong (favorableness) atau tidak menyokong (unfavorableness) pada pekerjannya. Tentu saja pilihan tersebut akan mempengaruhi bagaimana karyawan atau individu tersebut melaksanakan pekerjaannya Implikasi adanya ketidakpuasan adalah meningkatkan turnover, ketidak hadiran, maupun tingkat pekerjaan. Ini artinya bahwa kepuasan kerja akan mengurangi ketidakkerasanan karyawan dalam bekerja, meningkatkan jumlah kehadiran maupun kinerjanya (Mangkunegara, 2014). Kepuasan kerja merupakan hal yang bersifat individual dan tergantung pada persepsi seseorang tentang apa yang dirasakannya mengenai pekerjaan. Menurut (Hasibuan, 2010). Hasil penelitian ini sejalan dengan hasil penelitian terdahulu yang dilakukan oleh (Makaluas \& Sumampouw, 2017), (Adhan et al., 2020), (Jufrizen, 2017), (Jufrizen, 2016), (Syahputra \& Jufrizen, 2019), (Jufrizen et al., 2017), dan (Jufrizen et al., 2018) dan (Zahra \& Hidayat, 2017) menyimpulkan bahwa kepuasan kerja berpengaruh terhadap kinerja.

\section{Pengaruh Efikasi Diri Terhadap Kepuasan Kerja}

Dari hasil analisis pengujian hipotesis diketahui bahwa efikasi diri berpengaruh signifikan terhadap kepuasan kerja yang dinilai dengan koefisien jalur sebesar 0,565. Nilai probabilitas yang didapatkan adalah sebesar $0,000<0,05$, dengan nilai $t_{\text {hitung }}$ sebesar 5,408 , dan nilai tabel 1.96 , dengan demikian $t_{\text {hitung }}$ lebih besar dari $t_{\text {tabel }}(5,408>1.96)$ sehingga H0 ditolak (Ha diterima). Hal ini berarti efikasi diri berpengaruh signifikan terhadap kepuasan kerja pegawai pada Dinas Ketahanan Pangan Dan Peternakan Provinsi Sumatera Utara. Efikasi diri tinggi cenderung tidak mudah putus asa jika menghadapi kesulitan-kesulitan pekerjaan. Bagaimanapun rumitnya tugas dan pekerjaan yang harus dilakukan, orang dengan self efficacy tinggi akan cenderung termotivasi untuk dapat menyelesaikan, tidak ada motivasi untuk meninggalkan pekerjaan atau organisasinya hanya karena adanya kesulitan atau rintangan dalam menjalankan tugas dan pekerjaan (Subagyo, 2014).

Semakin baik penerapan efikasi diri, maka kepuasan kerja pegawai semakin meningkat dimana ketika individu mengalami kesenangan dalam bekerja, maka mereka akan melakukan pekerjaan lain di luar persepsi peran mereka atau kewajiban.

Hasil penelitian ini sejalan dengan hasil penelitian terdahulu yang dilakukan oleh (Dewi \& Sudibya, 2016) dan (Lodjo, 2013) yang menemukan bahwa efikasi diri mempunyai pengaruh positif terhadap kepuasan kerja.

\section{Pengaruh Beban Kerja Terhadap Kepuasan Kerja}


Dari hasil analisis pengujian hipotesis diketahui bahwa beban kerja berpengaruh signifikan terhadap kepuasan kerja yang dinilai dengan koefisien jalur sebesar 0,320. Nilai probabilitas yang didapatkan adalah sebesar $0,005<0,05$, dengan nilai thitung sebesar 2,790 dan nilai tabel 1.96 , dengan demikian $t_{\text {hitung }}$ lebih besar dari $t_{\text {tabel }}(2,790>1.96)$ sehingga $\mathrm{H} 0$ ditolak (Ha diterima). Hal ini berarti beban kerja berpengaruh signifikan terhadap kepuasan kerja pada kantor Dinas Ketahanan Pangan Dan Peternakan Provinsi Sumatera Utara.

Apabila seseorang memikul beban pekerjaan yang terlalu berat dan merasa tertekan maka besar kemungkinan orang tersebut akan merasakan ketidakpuasan terhadap pekerjaannya. Beban kerja yang terlalu berat yang disebabkan semakin ketatnya persaingan akan membuat karyawan lebih cepat mengalami stress dan kepanikan, sehingga tidak dapat menikmati pekerjaannya lagi. Karenanya porsi dari pembagian dari beban kerja harus disesuaikan dengan kemampuan atau kapasitas seseorang dalam menyelesaikan pekerjaannya (Bawono \& Nugraheni, 2015). Menurut (Tarwaka, 2014) menyimpulkan: "beban kerja merupakan suatu yang muncul dari interaksi antara tuntutan tugas, lingkungan kerja dimana digunakan sebagai tempat kerja, ketrampilan perilaku dan persepsi dari pekerjaan. Hasil penelitian ini sejalan dengan hasil penelitian terdahulu yang dilakukan oleh (Wijayanti, 2014) menyimpilkan bahwa beban kerja berpengaruh signifikan terhadap kepuasan kerja.

\section{Pengaruh Efikasi Diri Terhadap Kinerja Melalui Kepuasan Kerja}

Dari hasil analisis pengujian hipotesis diketahui bahwa efikasi diri berpengaruh signifikan terhadap kinerja melalui kepuasan kerja yang dinilai dengan koefisien jalur sebesar 0,096. Nilai probabilitas yang didapatkan adalah sebesar 0,005 $<0,05$, dengan nilai thitung sebesar 2,828, dan nilai $t_{\text {tabel }} 1.96$, dengan demikian $t_{\text {hitung }}$ lebih besar dari $t_{\text {tabel }}(2,828>1.96)$ sehingga $\mathrm{H} 0$ ditolak (Ha diterima). Hal ini berarti efikasi diri berpengaruh signifikan terhadap kinerja melalui kepuasan kerja pada Dinas Ketahanan Pangan Dan Peternakan Provinsi Sumatera Utara. Semakin baik penerapan efikasi diri, maka kepuasan kerja pegawai semakin meningkat dimana ketika individu mengalami kesenangan dalam bekerja, maka mereka akan melakukan pekerjaan lain di luar persepsi peran mereka atau kewajiban sehingga kinerja pegawai tersebuat akan semakin baik.

Semakin tinggi efikasi diri, maka semakin tinggi rasa percaya diri yang dimiliki dalam kemampuan untuk berhasil dalam suatu tugas. Individu dengan efikasi diri tinggi akan berusaha lebih keras untuk mengalahkan tantangan. Efikasi diri memainkan peran yang sangat besar dikarenakan dapat membantu seseorang dalam menentukan pilihan, usaha mereka untuk maju, kegigihan dan ketekunan yang mereka tunjukkan dalam mengahadapi kesulitan, dan derajat kecemasan atau ketenangan yang mereka alami saat mereka mempertahankan tugas-tugas yang mencakup kehidupan mereka. Self-efficacy merupakan salah satu kemampuan pengaturan diri individu. Self-efficacy mengacu pada persepsi tentang kemampuan individu untuk mengorganisasi dan mengimplementasi tindakan untuk menampilkan kecakapan tertentu (Muis et al., 2018).

\section{Pengaruh Beban Kerja Terhadap Kinerja Melalui Kepuasan Kerja}

Dari hasil analisis pengujian hipotesis diketahui bahwa beban kerja berpengaruh signifikan terhadap kinerja melalui kepuasan kerja yang dinilai dengan koefisien jalur sebesar 0,054. Nilai probabilitas yang didapatkan adalah sebesar 0,008 $<0,05$, dengan nilai $t_{\text {hitung }}$ sebesar 2,732, dan nilai $t_{\text {tabel }} 1.96$, dengan demikian $t_{\text {hitung }}$ lebih besar dari $t_{\text {tabel }}(2,732>1.96)$ sehingga $\mathrm{H} 0$ ditolak (Ha diterima). Hal ini berarti beban kerja 
berpengaruh signifikan terhadap kinerja melalui kepuasan kerja pada Dinas Ketahanan Pangan Dan Peternakan Provinsi Sumatera Utara. . Dalam hal ini hendaknya pada masa yang akan datang pemimpin agar memperhatikan kesejahteraan para pegawai, memberikan motivasi, memberikan pelatihan, memberikan penghargaan bagi yang memiliki kinerja bagus, memberikan kesempatan pendidikan lebih lanjut, promosi jabatan dan memberikan peluang untuk pengembangan karir bagi pegawai yang berprestasi. Apabila seseorang memikul beban pekerjaan yang terlalu berat dan merasa tertekan maka besar kemungkinan orang tersebut akan merasakan ketidakpuasan terhadap pekerjaannya akan mengurangi potensi kinerja karyawan.

Beban kerja adalah sekumpulan atau sejumlah kegiatan yang harus diselesaikan oleh suatu unit organisasi atau pemegang jabatan dalam jangka waktu tertentu (Sunarso, 2010) .

\section{KESIMPULAN}

Kesimpulan dari penelitian mengenai Pengaruh Efikasi Diri Dan Beban Kerja Terhadap Kinerja Melalui Kepuasan Kerja Pergawai Pada Kantor Dinas Ketahanan Pangan Dan Peternakan Provinsi Sumatera Utara adalah sebagai berikut.

1. Berdasarkan hasil penelitian secara langsung efikasi diri berpengaruh signifikan terhadap kinerja pegawai pada kantor Dinas Ketahanan Pangan Dan Peternakan Provinsi Sumatera Utara.

2. Berdasarkan hasil penelitian secara langsung beban kerja berpengaruh signifikan terhadap kinerja pegawai pada kantor Dinas Ketahanan Pangan Dan Peternakan Provinsi Sumatera Utara.

3. Berdasarkan hasil penelitian secara langsung kepuasan kerja berpengaruh signifikan terhadap kinerja pegawai pada kantor Dinas Ketahanan Pangan Dan Peternakan Provinsi Sumatera Utara.

4. Berdasarkan hasil penelitian secara langsung efikasi diri berpengaruh signifikan terhadap kepuasan kerja pegawai pada kantor Dinas Ketahanan Pangan Dan Peternakan Provinsi Sumatera Utara.

5. Berdasarkan hasil penelitian secara langsung beban kerja berpengaruh signifikan terhadap kepuasan kerja pegawai pada kantor Dinas Ketahanan Pangan Dan Peternakan Provinsi Sumatera Utara.

6. Berdasarkan hasil penelitian secara tidak langsung kepuasan kerja mampu memediasi pengaruh efikasi diri terhadap kinerja pegawai melalui kepuasan kerja pegawai pada kantor Dinas Ketahanan Pangan Dan Peternakan Provinsi Sumatera Utara

7. Berdasarkan hasil penelitian secara tidak langsung kepuasan kerja mampu memediasi pengaruh beban kerja terhadap kinerja pegawai melalui kepuasan kerja pegawai pada kantor Dinas Ketahanan Pangan Dan Peternakan Provinsi Sumatera Utara

\section{DAFTAR PUSTAKA}

Adhan, M., Jufrizen, J., Prayogi, M. A., \& Siswadi, Y. (2020). Peran Mediasi Komitmen Organisasional pada Pengaruh Kepuasan Kerja terhadap Kinerja Dosen Tetap Universitas Swasta di Kota Medan. Jurnal Samudera Ekonomi Dan Bisnis, $11(1), 1-15$.

Bandura, A. (2010). Self Efficacy: The Exercise of Control. W.H Freemen \& Company.

Bawono, D. C., \& Nugraheni, R. (2015). Analisis Pengaruh Pemberian Intensif, Kepemimpinan dan Beban Kerja Terhadap Kinerja Perawat (Studi Pada Perawat Ruang Rsud Kota Semarang). Diponegoro Journal Of Management, 4(3), 30- 
44.

Chaterina, R. (2012). Hubungan Antara Beban Kerja Dengan Kinerja Karyawan Offshore Pada Divisi Quality Assurance Quality Contol Di Pertamina Hulu Energi Onwjltd Jakarta. Universitas Indonesia.

Dewi, N. M. S., \& Sudibya, I. G. A. (2016). Pengaruh Efikasi Diri Terhadap Organizational Citizenship Behavior Dengan Kepuasan Kerja Sebagai Variabel Mediasi. E-Jurnal Manajemen Unud, 5(1), 7473-7499.

Dwi, M. (2020). Pengaruh Audit Delay dan Beban Kerja Terhadap Kualitas Audit Dengan Rotasi Audit Sebagai Variabel Moderasi (Pada Perusahaan Manufaktur Sektor Industri Dasar dan Kimia Yang Terdaftar di Bursa Efek Indonesia. Universitas Muhammadiyah Palembang.

Feist, J., \& Feist, G. (2010). Teori Kepribadian. Salemba Humanika.

Ghufron, M. N., \& Risnawati, R. (2010). Teori Teori Psikologi. Ar-Ruzz Media.

Handoko, H. (2000). Manajemen Personalia. BPFE.

Hasibuan. (2010). Manajemen Sumber Daya Manusia.

Jufrizen, J. (2016). Efek Mediasi Kepuasan Kerja Pada Pengaruh Kompensasi Terhadap Kinerja Karyawan. Jurnal Ilmiah Manajemen Dan Bisnis, 17(1).

Jufrizen, J. (2017). Pengaruh Kepemimpinan dan Budaya Organisasi Terhadap Kinerja dengan Kepuasan Kerja sebagai Variabel Intervening. Jurnal Ilmiah Kohesi, 1(1), 166-177.

Jufrizen, J., Gultom, D. K., Sitorus, S. A., Sari, M., \& Nasution, M. I. (2018). The Effect of Organizational Culture and Islamic Work Ethic on Permanent Lecturers' Job Satisfaction, Organizational Commitment And Work Performance at Private Islamic Universities in the City of Medan. Proceeding 1st International Conference of Economic Studies (ICOES) 2018, 179-186.

Jufrizen, J., Lumbanraja, P., Salim, S. R. A., \& Gultom, P. (2017). The Effect of Compensation, Organizational Culture and Islamic Work Ethic Towards the Job Satisfaction and the Impact on the Permanent Lecturers. International Business Management, 11(1), 53-60.

Lodjo, F. S. (2013). Pengaruh Pelatihan, Pemberdayaan dan Efikasi diri Terhadap Kepuasan Kerja. Jurnal EMBA: Jurnal Riset Ekonomi, Manajemen, Bisnis Dan Akuntansi, 1(3), 747-755.

Makaluas, C. G., \& Sumampouw, H. j. (2017). Pengaruh Kepuasan Kerja Terhadap Kinerja Karyawan Pada PT. BPR Prisma Dana Manado. Jurnal Administrasi Bisnis (JAB), 5(5), 1-13.

Mangkunegara, A. A. (2014). Evaluasi Kinerja Sumber Daya Manusia. Refika Aditama. Moekijat. (2010). Manajemen Sumber Daya Manusia. Mandar Maju.

Muis, M. R., Nasution, M. I., Azhar, M. E., \& Radiman, R. (2018). Pengaruh kepemimpinan dan self efficacy terhadap kelelahan emosional serta dampaknya terhadap kepuasan kerja dosen. Jurnal Riset Sains Manajemen, 2(3), 131-142. https://doi.org/10.5281/zenodo.1477532

Nooralizad, R., Nadeholi, G., \& Parivash, J. (2011). A causal model depicting the influence of spiritual leadership and some organization and individual variables on workplace spirituality. Journal of Advance in Management, 4(5), 90-99.

Rolos, J. K. R., Sambul, S. A. P., \& Rumawas, W. (2018). Pengaruh Beban Kerja Terhadap Kinerja Karyawan Pada PT. Asuransi Jiwasraya Cabang Manado Kota. Jurnal Administrasi Bisnis (JAB), 6(4), 97-111.

Saraswati, A. A. N. D., Dewi, I. M., \& Piartini, P. S. (2017). Pengaruh Efikasi Diri 
Terhadap Kinerja Dengan Dukungan Organisasional Sebagai Pemoderasi. EJurnal Udayana, 1(1), 2257-2286.

Siagian, S. P. (2014). Manajemen dan Evaluasi Kinerja. Bumi Aksara.

Subagyo, A. (2014). Pengaruh Lingkungan Kerja dan SelfEfficacy Terhadap Komitmen Organisasional Dosen Politeknik Negeri Semarang. Orbith, 10(1), 74-81.

Sunarso. (2010). Pengaruh Kepemimpinan, Kedisiplinan, Beban Kerja dan Motivasi Kerja Terhadap Kinerja Guru Sekolah. Management Sumber Daya Manusia, $4(1)$.

Sutrisno, E. (2010). Manajemen Sumber Daya Manusia. Erlangga.

Sutrisno, Edy. (2010). Manajemen Sumber Daya Manusia. Penerbit Kencana.

Syahputra, I., \& Jufrizen, J. (2019). Pengaruh Dilkat, Promosi dan Kepuasan Kerja Terhadap Kinerja Pegawai. Manggeio: Jurnal Ilmiah Magister Manajemen, 2(1), 104-116.

Tarwaka. (2014). Ergonomi Industri; Dasar-dasar Pengetahuan Ergonomi dan Aplikasi di Tempat Kerja. Harapan Press.

Taurisa, C. M., \& Ratnawati, I. (2012). Analisis Pengaruh Budaya Organisasi dan Kepuasan Kerja Terhadap Komtimen Organisasi Dalam Meningkatkan Kerja Karyawan Studi Pada PT. Sido Muncul Kaligawe Semarang. Jurnal Bisnis Dan Ekonomi, 19(2), 170-187.

Wibowo, W. (2010). Manajemen Kinerja. Rajawali Pres.

Wijayanti. (2014). Pengaruh Dukungan Organisasi dan Efikasi Diri Terhadap Kepuasan Melalui Komitemen Organisasi. Jurnal Bisnis Dan Manajemen, 6(2), 77-88.

Yulianita. (2017). Pengaruh Kompensasi Terhadap Kepuasan Kerja Karyawan Pada PT. Gemilang Utama Ideal Palembang. Jurnal Adminika, 3(1), 70-71.

Zahra, R. N., \& Hidayat, H. (2017). Pengaruh Kepuasan Kerja dan Disiplin Kerja Terhadap Kinerja Karyawan Bank di Kota Batam. Journal Of Applied Managerial Accounting, 1(2), 1-13. 